\author{
Zbigniew Janusz Ożdżyński \\ Zespół Szkół im. St. Staszica, \\ Gąbin
}

\title{
Przedsiębiorczość w edukacji dzieci i młodzieży dla świadomego i bezpiecznego uczestnictwa w ruchu drogowym
}

Bezpieczeństwo w ujęciu ogólnym to stworzenie poczucia braku zagrożenia. O bezpieczeństwie w transporcie można powiedzieć, że jest to ogół warunków i instytucji chroniących życie, zdrowie i mienie osób (także podmiotów prawnych) w dowolny sposób związanych z procesami transportu (Merkisz, Nowakowski, Smalko 2007). Ruch drogowy tworzą trzy zasadnicze grupy czynników: pojazdy, użytkownicy drogi (uczestnicy ruchu) oraz środowisko drogi. Od cech wymienionych grup zależy przebieg procesu ruchu i jego konsekwencje, w tym zagrożenia bezpieczeństwa dla jego uczestników (Chmielewski, Szczuraszek 2005). Bezpieczeństwo ruchu drogowego w ujęciu ogólnym to stworzenie poczucia braku zagrożenia jego uczestników. Z kolei przedsiębiorczość, pod którą rozumie się aktywność konkretnych osób (w organizacji, gminie itp.), może być postrzegana jako proces realizacji przedsięwzięcia, obejmujący: dostrzeżenie okazji do wykorzystania, decyzję o jej wykorzystaniu i poniesieniu pewnego ryzyka, działania zarządcze często połączone z działaniami wykonawczymi, które powinny przynosić określone korzyści (Huczek 2009). Według T. Brzozowskiego przedsiębiorczość z jednej strony to zdolność do tego, żeby być przedsiębiorczym, dążenie do ciągłej zmiany, doskonalenie produkcji, wymiany i konsumpcji, stwarzanie nowych, lepszych możliwości zaspokajania potrzeb i funkcjonowania przedsiębiorstw, działania i przedsięwzięcia, polegające na dążeniu do zysku, z drugiej zaś ciągłe stwarzanie czegoś nowego, innowatorstwo, indywidualna cecha ludzkiej osobowości, zdolność do organizowania działalności handlowej, działalność konkurencyjna, ekonomiczny puls społeczeństwa, proces samoniszczący, podstawa i warunek innowacyjnego rozwoju gospodarki, indywidualnej zamożności, zachowanie człowieka lub organizacji, wreszcie skłonność do innowacji, wrażliwość na zmiany (Brzozowski 2007). W dokonanym zestawieniu wniosków wynikających $\mathrm{z}$ analizy definicji przedsiębiorczości Brzozowski rozróżnia dwie sfery przedsiębiorczości: sferę uczuciową i sferę świadomego czynu oraz działania.

Rozróżnienie tych sfer znajduje się również w definicji zawartej w podręczniku do przedmiotu podstawy przedsiębiorczości, w którym Z. Makieła i T. Rachwał definiują przedsiębiorczość jako zespół określonych cech osobowości człowieka, pozwalających mu aktywnie uczestniczyć w życiu społeczno-gospodarczym (w tym także rodzinnym) oraz czerpać z niego wiele radości i satysfakcji. Człowiek przedsiębiorczy potrafi kreować nowe potrzeby dla siebie i innych, a także zaspokajać je niezależnie od warunków otoczenia (Makieła, Rachwał 2010). By zaspokoić wykreowane potrzeby, człowiek musi podjąć działania. Jak stwierdza Brzozowski, oznacza to, że człowiek musi podjąć świadomy i zaplanowany wysiłek na rzecz wprowadzenia zmiany w otaczającej go rzeczywistości, jest skutkiem uprzedniego odczucia pewnego 
braku..., który - oddziałując na podmiot - budzi w nim określone pragnienie. Pragnienie uzupełnienia uznanego braku staje się źródłem potrzeby, wyzwala zatem w człowieku chęć oraz wolę działania w celu osiągnięcia stanu znoszącego potrzebę (Brzozowski 2009).

$\mathrm{Na}$ podstawie przedstawionych definicji bezpieczeństwa, bezpieczeństwa w ruchu drogowym oraz przedsiębiorczości w niniejszej pracy podjęto próbę sformułowania definicji przedsiębiorczości w ruchu drogowym. Przez przedsiębiorczość w ruchu drogowym rozumie się podejmowanie innowacyjnych działań polegających na opracowaniu i zastosowaniu nowych rozwiązań, nowatorskiego zastosowania już istniejących rozwiązań zmierzających do przywrócenia stanu braku zagrożenia w obszarach wszystkich czynników tworzących ruch drogowy. Działania te są skutkiem utraty przez człowieka, jako uczestnika ruchu drogowego, poczucia braku zagrożenia. Utrata ta wyzwala w uczestniku ruchu drogowego pragnienie przywrócenia stanu niezagrożenia poprzez chęć i działanie w tym kierunku.

Szczególnym obszarem działań przedsiębiorczych jest edukacja dla świadomego i bezpiecznego uczestnictwa w ruchu drogowym. Edukacja to ogół procesów oraz zabiegów oświatowych i wychowawczych - przede wszystkim zamierzonych, lecz również okazjonalnych - których celem jest wyposażenie wychowanków w wiedzę i umiejętności, a także ukształtowanie ich osobowości stosownie do uznawanych w danym społeczeństwie wartości i ideału wychowawczego (Kupisiewicz Cz., Kupisiewicz M. 2009) (ryc. 1).

Ryc. 1. Edukacja i jej podsystemy

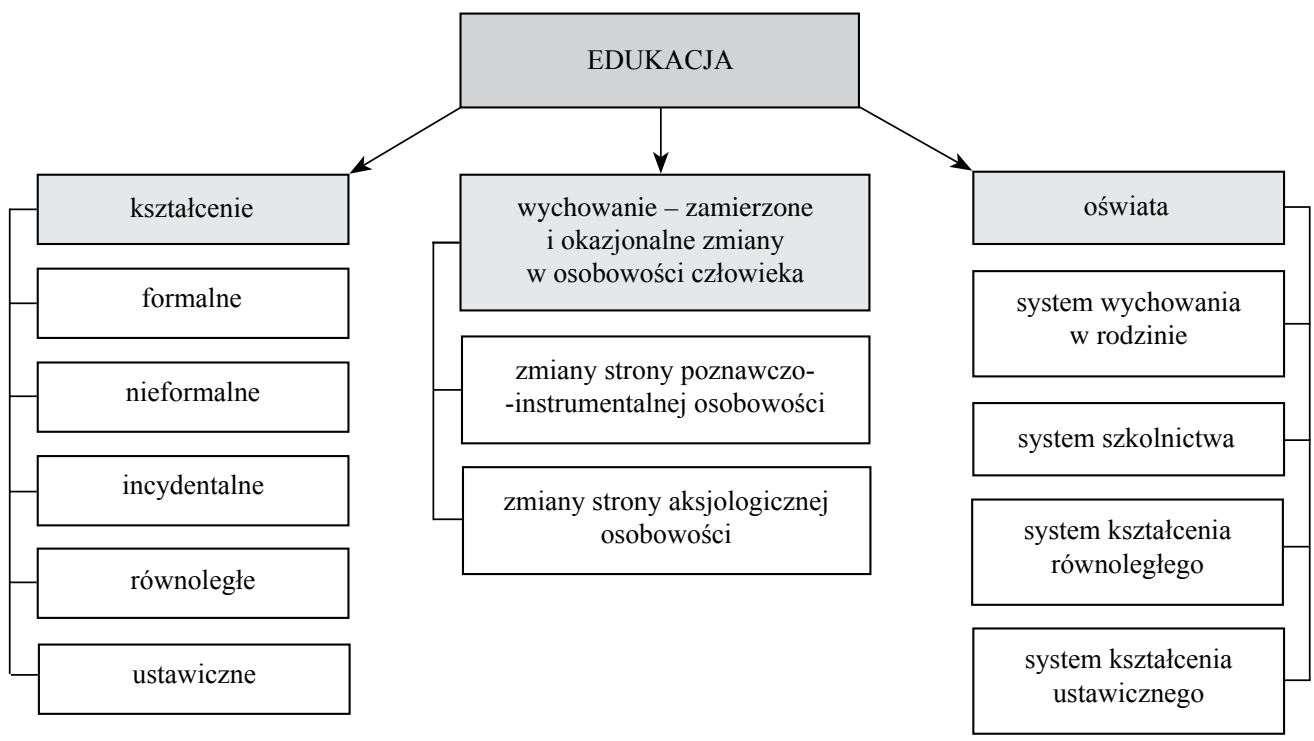

Źródło: opracowanie własne na podstawie: Okoń 1998.

Wiedza nie jest pojęciem łatwo definiowalnym, ponieważ odnosi się do wielu rodzajów aktywności człowieka. Wyróżnia się wiedzę intelektualną, polegającą na przyswajaniu faktów, pojęć, teorii i praw samodzielnym lub z pomocą nauczyciela; wiedzę emocjonalną, polegającą na poznawaniu wartości dzięki wiedzy o świecie, oraz wiedzę praktyczną, która polega na zdobywaniu różnorodnych umiejętności. Według W. Okonia wiedza to treści utrwalone w umyśle ludzkim w rezultacie gromadzenia doświadczeń i uczenia się. Wiedza obejmuje wszystkie 
formy świadomości społecznej, a więc formę najwyższą - naukę (Okoń 1998). Według państwa Kupisiewiczów, wiedza to ogół informacji o przyrodzie, społeczeństwie, kulturze i technice wraz z umiejętnością ich przechowywania, przetwarzania oraz wykorzystania do celów teoretycznych i praktycznych (Kupisiewicz Cz., Kupisiewicz M. 2009). Państwo Kupisiewiczowie oraz W. Okoń wyróżniają dwa rodzaje wiedzy: praktyczną i teoretyczną.

Umiejętność to sprawność w posługiwaniu się odpowiednimi wiadomościami przy wykonywaniu określonych zadań; wiadomości te występują w postaci normatywnej jako zasady, prawidła, reguły lub - w wypadku naśladownictwa - jako wzorce postępowania (Okoń 1998). Przez wychowanie rozumie się świadomie zorganizowaną działalność społeczną, której celem jest wywołanie zamierzonych zmian w osobowości człowieka. Zmiany te obejmują stronę poznawczo-instrumentalną związaną z poznaniem rzeczywistości i umiejętność oddziaływania na nią, jak i stronę aksjologiczną, która polega na kształtowaniu stosunku człowieka do świata i ludzi, jego przekonań i postaw, układu wartości i celu życia (Okoń 1998).

Pojęcie świadomość definiowane jest w różny sposób w takich naukach, jak psychologia, filozofia i pedagogika. Definicje te łączy jednak wspólny wątek określający świadomość jako „właściwą człowiekowi zdolność do zdawania sobie sprawy z własnego zachowania, jego uwarunkowań i konsekwencji” (Okoń 1998). Na tej podstawie można sformułować pojęcie świadomego i bezpiecznego uczestnictwa dzieci i młodzieży w ruchu drogowym: dziecko lub młody człowiek zdaje sobie sprawę z faktu uczestniczenia w ruchu drogowym, zna aktualnie obowiązujące przepisy Prawa o ruchu drogowym, przestrzega ich, jest kulturalnym uczestnikiem ruchu drogowego oraz szanuje prawa innych użytkowników dróg.

\section{Kierunki działań dla obszaru edukacji dzieci i młodzieży}

Wykształcenie świadomego uczestnika ruchu drogowego wymaga intensywnych przedsiębiorczych działań edukacyjnych skierowanych do całego społeczeństwa ze szczególnym uwzględnieniem dzieci i młodzieży. W Krajowym Programie Bezpieczeństwa Ruchu Drogowego Gambit $2005^{1}$ zaproponowano następujące kierunki działań dla obszaru edukacji dzieci i młodzieży (Priorytet 1.3. Działania sektorowe: Działanie 1: Doskonalenie szkolnej edukacji na rzecz bezpieczeństwa ruchu drogowego):

- podjęcie systematycznych działań edukacyjnych w zakresie edukacji dla bezpieczeństwa ruchu drogowego,

- stały rozwój bazy techniczno-dydaktycznej i metodycznej szkół,

- organizacja pozaszkolnych działań edukacyjnych z zakresu bezpieczeństwa ruchu drogowego, wspomagających edukację szkolną,

- organizacja inspirujących form edukacji i aktywizacji rodziców.

W programie Gambit 2005 stwierdza się, że „prawidłowo funkcjonujący system szkolnej edukacji na rzecz bezpieczeństwa ruchu drogowego jest elementem niezbędnym dla wykształcenia świadomego, kulturalnego uczestnika ruchu drogowego. Dlatego konieczne jest realizowanie treści programowych dotyczących bezpieczeństwa ruchu drogowego na każdym etapie nauczania”. Przy takim założeniu zachodzi konieczność podjęcia systematycznych działań edukacyjnych w zakresie bezpieczeństwa w ruchu drogowym na wszystkich etapach edukacji, od przedszkola zaczynając i na szkole ponadgimnazjalnej, niezależnie od realizowanego przez nią kierunku kształcenia, kończąc. W tym samym programie Gambit 2005 stwierdza się również,

\footnotetext{
${ }^{1}$ Podstawą opracowania programu były następujące dokumenty: Polityka transportowa UE na lata 2001-2010, III Program BRD Unii Europejskiej, Polityka Transportowa Polski na lata 2006-2025.
} 
że „wychowanie komunikacyjne realizowane jako interdyscyplinarne zadanie szkoły, powinno znaleźć swoje odzwierciedlenie w programach i podręcznikach różnych przedmiotów nauczania (dotyczy programów i podręczników nowych, ubiegających się o dopuszczenie do użytku szkolnego)". Do realizacji tego założenia konieczne jest opracowanie programów nauczania do wszystkich przedmiotów realizowanych na poszczególnych etapach kształcenia zawierających wspólne zagadnienia dotyczące świadomego i bezpiecznego uczestnictwa w ruchu drogowym. Treści odnoszące się do świadomego i bezpiecznego uczestnictwa dzieci i młodzieży w ruchu drogowym zawarte w tych programach powinny się wzajemnie uzupełniać, być ze sobą ściśle skorelowane, a ich realizacja winna być zsynchronizowana w czasie. Do prawidłowej realizacji treści programowych dotyczących zagadnień bezpieczeństwa w ruchu drogowym konieczna jest nowoczesna baza techniczno-dydaktyczna i metodyczna przedszkoli oraz szkół, pozwalająca na pełne wykorzystanie w nauczaniu metod symulacyjnych i ćwiczeń praktycznych. Jednym z bardzo dobrych rozwiązań mogłyby być wyłączone z ruchu miasteczka ruchu drogowego wyposażone w znaki pionowe i poziome oraz sygnalizację świetlną, dostosowane do realizowanego poziomu kształcenia i znajdujące się przy każdym przedszkolu, szkole podstawowej, gimnazjum i szkole ponadgimnazjalnej niezależnie od realizowanego przez tę szkołę kierunku kształcenia (ryc. 2).

Ryc. 2. Stacjonarne miasteczko ruchu drogowego przy przedszkolu nr 6 w Płocku
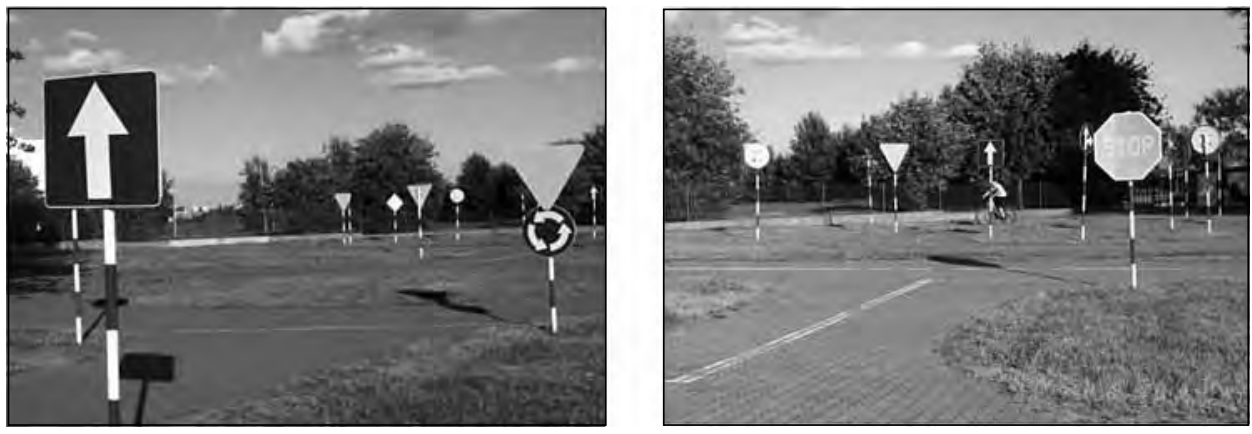

Źródło: zdjęcia własne, wrzesień 2011.

Kiedy nie ma możliwości budowy stacjonarnych miasteczek ruchu drogowego, dobrym rozwiązaniem są miasteczka mobilne, które mogą dotrzeć do dzieci i młodzieży w małych miejscowościach. Mobilne miasteczko może być zbudowane ze zwijanych gumowych mat, które tworzą skrzyżowania (ryc. 3a) lub wyznaczone za pomocą linii i słupków z tyczkami na wyłączonym z ruchu placu (ryc. 3b), który jest wyposażony w znaki poziome i pionowe. W programie Gambit 2005, w Działaniu 1: Doskonalenie szkolnej edukacji na rzecz bezpieczeństwa ruchu drogowego, Priorytet 1.3: Działania sektorowe stwierdza się, że konieczne jest „organizowanie pozaszkolnych działań edukacyjnych z zakresu bezpieczeństwa ruchu drogowego, wspomagających edukację szkolną". Mogą to być turnieje lub zawody rowerowe, młodzieżowe turnieje motoryzacyjne, konkursy plastyczne, małe formy teatralne, pikniki bezpieczeństwa ruchu drogowego i inne imprezy promujące świadome i bezpieczne uczestnictwo w ruchu drogowym oraz szacunek dla innych jego uczestników, dostosowane do etapu kształcenia. Ciekawym działaniem przedsiębiorczym wspomagającym edukację szkolną może być możliwość jazdy gokartami po wyłączonych z ruchu torach, która pozwala na opanowanie i doskonalenie techniki jazdy i jest doskonałym wstępem do przyszłego świadomego i bezpiecznego uczestnictwa w ruchu drogowym (ryc. 4). 
Ryc. 3. Mobilne miasteczka ruchu drogowego: a) zbudowane ze zwijanych gumowych mat, b) wyznaczone na placu wyłączonym z ruchu
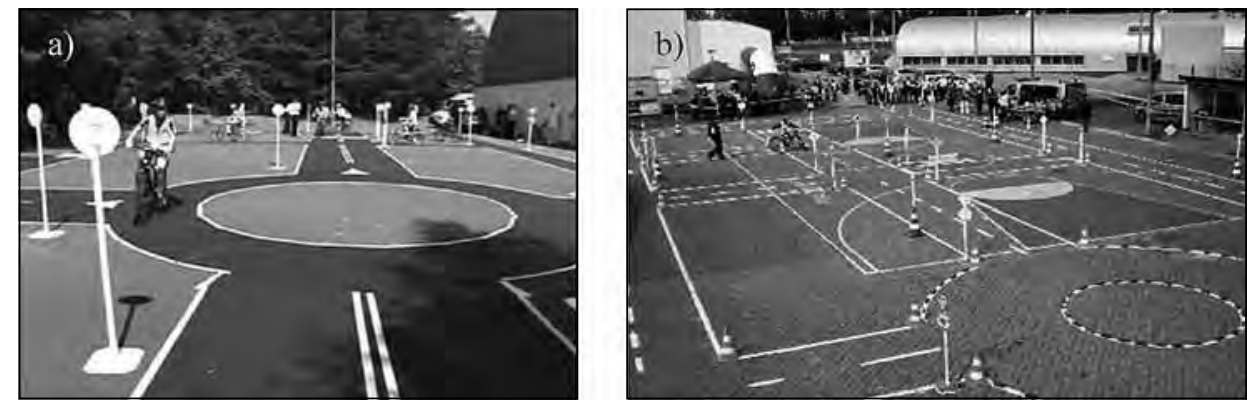

Źródło: ryc. 3a - http://www.poranny.pl/apps/pbcs.dll/article?AID=/20110126/BIALYSTOK/585798056 (sierpień 2011); ryc. 3b - http://www.grupaimage.com.pl/?s=prd\&i=informacja\&id=14559 (sierpień 2011).

Ryc. 4. Jazda treningowa gokartami na wyłączonym z ruchu torze

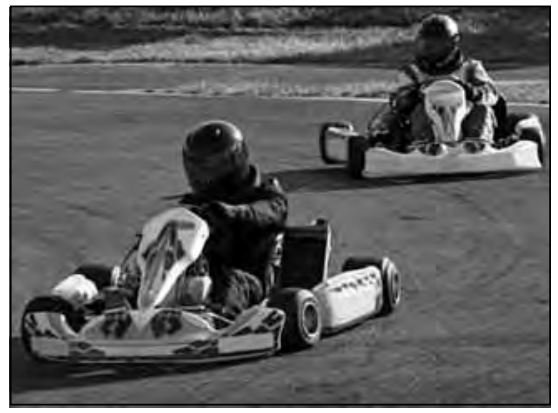

Źródło: http://www.wyjatkowyprezent.pl/jazda-gokarty-2osoby (sierpień 2011).

Równocześnie, zgodnie z Działaniem 1 Priorytetu 1.3 programu Gambit 2005, powinny być prowadzone działania w postaci ,inspirujących form edukacji i aktywizacji rodziców”. Obecnie prowadzony jest przez Krajową Radę Bezpieczeństwa Ruchu Drogowego cykl kampanii społecznych o charakterze edukacyjno-informacyjnym pod wspólną nazwą „Włącz myślenie”, np. „Zapnij pasy”, „Prędkość zabija” czy „Nie jedź na kacu”. Generalna Dyrekcja Dróg Krajowych i Autostrad wspólnie z Policją jest organizatorem kampanii pod nazwą Narodowy Eksperyment Bezpieczeństwa „Weekend bez Ofiar”, której celem jest zbudowanie koalicji wszystkich uczestników ruchu drogowego: kierowców, pasażerów, rowerzystów i pieszych wokół idei bezpieczeństwa drogowego. Policja organizuje liczne akcje profilaktyczne, np. „Bezpieczny przejazd”, „Bezpieczeństwo dziecka w podróży”, „Pasy bezpieczeństwa” czy „Bezpiecznie na rowerze". Mogą to być również festyny, pikniki czy turnieje rodzinne i inne formy edukacji oraz aktywizacji rodziców o zasięgu lokalnym lub większym promujące bezpieczne i prawidłowe zachowania osób dorosłych w ruchu drogowym. Edukacja rodziców i dziadków to bardzo ważny element kształcenia społeczeństwa dla bezpieczeństwa ruchu drogowego, gdyż to właśnie dorośli członkowie rodziny są dla dzieci i młodzieży wzorem do naśladowania, a ich nieprawidłowe, niezgodne z zasadami bezpieczeństwa w ruchu drogowym zachowanie często niweczy efekty edukacji przedszkolnej i szkolnej dzieci i młodzieży w tym zakresie (ryc. 5). 
Ryc. 5. Nieprawidłowe przejście przez jezdnię osób dorosłych, w tym matki z dwójką dzieci: a) oczekiwanie matki z dziećmi na możliwość przejścia przez jezdnię oraz przejście osoby dorosłej, b) zakończenie przejścia przez jezdnię przez matkę z dziećmi
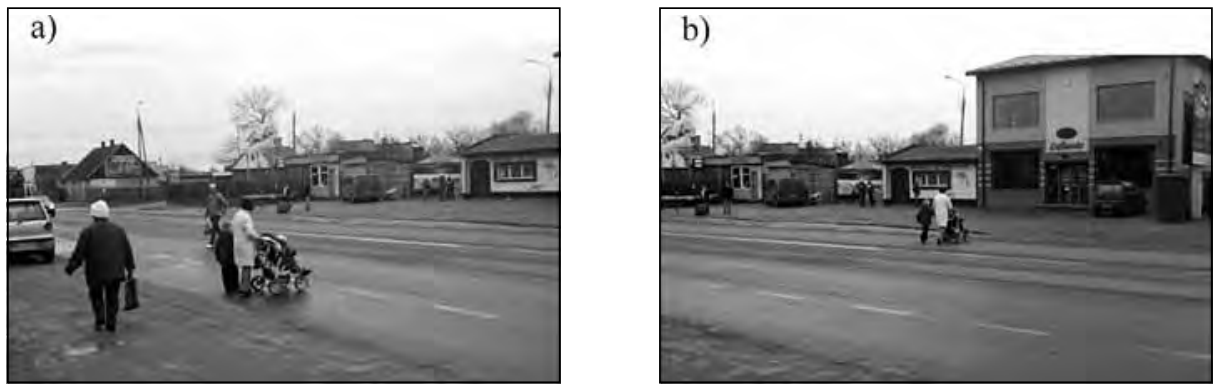

Źródło: http://www.inwestycje.radom.pl/forum/printview.php?t=739\&start=0\&sid=9e3d5019f6930361eaf7376b157575a1 (sierpień 2011).

Celem omówionych działań przedsiębiorczych w obszarze edukacji jest ukształtowanie u uczestnika ruchu drogowego postawy świadomego i kulturalnego uczestnictwa w tymże ruchu, szacunku dla innych użytkowników dróg, przestrzegania prawa, w tym Prawa o ruchu drogowym, co w konsekwencji doprowadzi do poprawy bezpieczeństwa na polskich drogach. Do prawidłowej i skutecznej realizacji postawionych w programie Gambit 2005 zadań potrzebna jest dobrze przygotowana kadra szkoleniowa, posiadająca obiektywną i rzetelną wiedzę w zakresie bezpieczeństwa ruchu drogowego, traktująca realizację tego zadania poprzez pryzmat ochrony życia i zdrowia. Kadra pedagogiczna to nie tylko szkolni nauczyciele dzieci i młodzieży, to także nauczyciele akademiccy, egzaminatorzy, wykładowcy na kursach dla instruktorów nauki jazdy i instruktorzy nauki jazdy. Nauczyciele szkolni oraz nauczyciele akademiccy mają przygotowanie pedagogiczne, lecz ich wiedza z zakresu bezpieczeństwa ruchu drogowego często oparta jest na szkoleniu kursowym w zakresie prawa jazdy kategorii B. Trudna będzie zatem realizacja jednego z podstawowych zadań zapisanych w programie Gambit 2005, polegającego na podniesieniu jakości kształcenia i doskonalenia zawodowego nauczycieli i osób prowadzących szkolenia uczestników ruchu drogowego.

\section{Wypadki drogowe w Polsce a zamierzenia programu Gambit 2005}

Z przedstawionych w tabeli 1 danych statystycznych Policji wynika, że liczba ofiar śmiertelnych w roku 2007 wzrosła o 340 osób w porównaniu z rokiem 2006. W następnych latach nastąpił początkowo powolny spadek (w roku 2008 o 146 osób w stosunku do roku 2007), następnie w roku 2009 duży spadek ofiar śmiertelnych wynoszący 865 osób. Od roku 2008 następuje spadek liczby wypadków, by w roku 2010 osiągnąć poziom 38 832, tj. o 5364 zdarzenia mniej niż w roku 2009. Również od roku 2008 nastąpił spadek liczby zabitych, by w roku 2010 osiągnąć poziom 3907 ofiar śmiertelnych, tj. o 665 osób mniej w porównaniu z rokiem 2009. Oznacza to spowolnienie tempa spadku liczby śmiertelnych ofiar wypadków drogowych w porównaniu z rokiem 2009, w którym spadek liczby zabitych wyniósł 865 osób w stosunku do roku 2008. 
Tab. 1. Wypadki drogowe i ich skutki w Polsce w latach 2006-2010

\begin{tabular}{|l|c|c|c|c|c|}
\hline \multirow{2}{*}{\multicolumn{1}{|c|}{ Opis }} & \multicolumn{5}{c|}{ Rok } \\
\cline { 2 - 6 } & $\mathbf{2 0 0 6}$ & $\mathbf{2 0 0 7}$ & $\mathbf{2 0 0 8}$ & $\mathbf{2 0 0 9}$ & $\mathbf{2 0 1 0}$ \\
\hline Liczba wypadków & 46876 & 49536 & 49054 & 44196 & 38832 \\
\hline Skutki: & \multicolumn{5}{|c|}{} \\
\hline zabici & 5243 & 5583 & 5437 & 4572 & 3907 \\
\hline ranni & 59123 & 63224 & 62097 & 56046 & 48952 \\
\hline Nietrzeźwi kierowcy & 201192 & 159346 & 168612 & 173324 & 165885 \\
\hline
\end{tabular}

Źródło: opracowanie własne na podstawie danych statystycznych KG Policji,http://dlakierowcow.policja. $\mathrm{pl} /$ portal/dk/807/47493/Wypadki_drogowe_raporty_roczne.html (lipiec 2011).

Analogiczną prawidłowość można zauważyć, analizując dane zawarte w tabelach 2 i 3 , które dotyczą długich weekendów. W roku 2007 nastąpił wzrost liczby wypadków w porównaniu z rokiem 2006 (o 348 zdarzeń w weekend majowy i o 186 zdarzeń w weekend sierpniowy), a od roku 2008 nastąpił spadek liczby wypadków, by w roku 2010 osiągnąć poziom 453 zdarzeń w weekend majowy i 381 zdarzeń w weekend sierpniowy. Liczba ofiar śmiertelnych od roku 2008 również zmalała, by w roku 2010 osiągnąć poziom 37 osób zarówno w weekend majowy, jak i w weekend sierpniowy.

Tab. 2. Statystyka wypadków drogowych w Polsce w długie majowe weekendy w latach 2006-2010

\begin{tabular}{|l|c|c|c|c|c|}
\hline \multirow{2}{*}{\multicolumn{2}{|c|}{ Opis }} & \multicolumn{5}{c|}{ Rok } \\
\cline { 2 - 6 } & $\mathbf{2 0 0 6}$ & $\mathbf{2 0 0 7}$ & $\mathbf{2 0 0 8}$ & $\mathbf{2 0 0 9}$ & $\mathbf{2 0 1 0}$ \\
\hline Liczba wypadków & 710 & 1058 & 631 & 440 & 453 \\
\hline Skutki: & \multicolumn{5}{|c|}{} \\
\hline zabici & 77 & 112 & 54 & 58 & 37 \\
\hline ranni & 977 & 1479 & 877 & 553 & 587 \\
\hline Nietrzeźwi kierowcy & 3520 & 4044 & 2513 & 2046 & 2335 \\
\hline
\end{tabular}

Źródło: opracowanie własne na podstawie danych statystycznych KG Policji, http://dlakierowcow.policja. pl/portal/dk/834/47562/Weekend_majowy.html (lipiec 2011).

Tab. 3. Statystyka wypadków drogowych w Polsce w długie sierpniowe weekendy w latach 2006-2010

\begin{tabular}{|l|c|c|c|c|c|}
\hline \multirow{2}{*}{\multicolumn{1}{|c|}{ Opis }} & \multicolumn{5}{c|}{ Rok } \\
\cline { 2 - 6 } & $\mathbf{2 0 0 6}$ & $\mathbf{2 0 0 7}$ & $\mathbf{2 0 0 8}$ & $\mathbf{2 0 0 9}$ & $\mathbf{2 0 1 0}$ \\
\hline Liczba wypadków & 561 & 747 & 561 & 389 & 381 \\
\hline Skutki: & \multicolumn{5}{|c|}{} \\
\hline zabici & 80 & 79 & 56 & 33 & 37 \\
\hline ranni & 843 & 1019 & 829 & 558 & 521 \\
\hline Nietrzeźwi kierowcy & 3471 & 2794 & 1840 & 1777 & 2081 \\
\hline
\end{tabular}

Źródło: opracowanie własne na podstawie danych statystycznych KG Policji, http://dlakierowcow.policja. pl/portal/dk/834/47565/Weekend_sierpniowy.html (lipiec 2011). 
Celem głównym przyjętej w Polsce wizji bezpieczeństwa ruchu drogowego, zwanej Wizją ZERO, jest: ,zdążanie do całkowitego wyeliminowania ofiar śmiertelnych” (Gambit 2005). Plan realizacji Wizji ZERO w Polsce przestawiono na rycinie 6.

Ryc. 6. Plan realizacji Wizji ZERO w Polsce

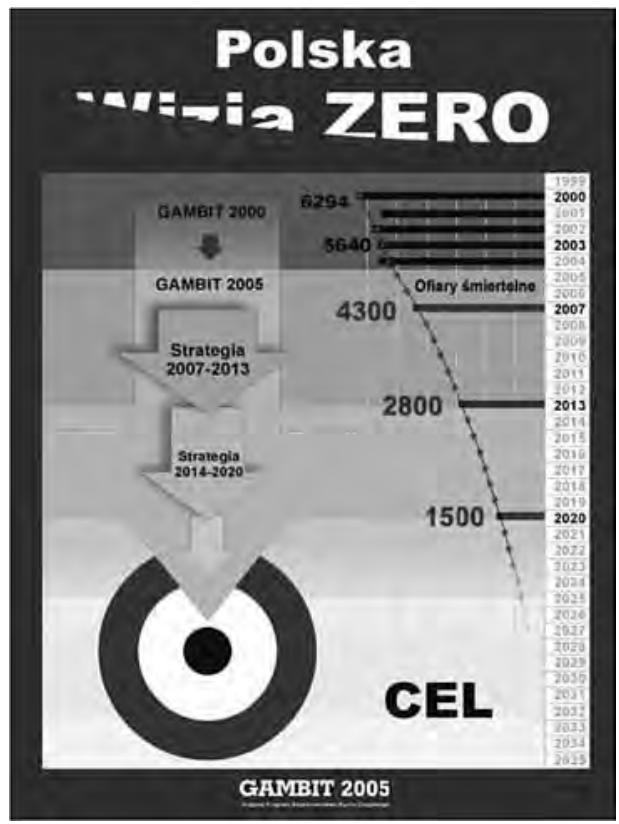

Źródło: program Gambit 2005.

W programie Gambit 2005 stwierdza się, że „,cel główny realizowany będzie etapowo; co siedem lat ustalane będą liczbowe cele określające zamierzenia władz państwowych odnośnie dalszej redukcji liczby ofiar śmiertelnych w transporcie". Jako dwa pierwsze etapowe cele strategiczne na drodze do osiągnięcia założonej wizji przyjęto obniżenie liczby ofiar śmiertelnych w wypadkach drogowych:

- do poziomu nie więcej niż 2800 osób w roku 2013,

- do poziomu nie więcej niż 1500 osób w roku 2020.

Cele te określono, wychodząc z założenia, że w dwóch pierwszych etapach należy osiągnąć stabilizację na poziomie zbliżonym do krajów o najlepszych obecnie wskaźnikach bezpieczeństwa (Szwecja, Wielka Brytania, Holandia, Australia, Kanada) (Gambit 2005). Jako rezultaty skutecznej realizacji Wizji ZERO do roku 2020 stwierdza się, że program Gambit 2005: „może przynieść zmniejszenie o ponad 40 tys. łącznej liczby ofiar śmiertelnych i o ponad 500 tys. łącznej liczby ofiar rannych. Zmniejszenie strat z tego powodu szacuje się na poziomie ponad $230 \mathrm{mld} z \nmid, \mathrm{tj}$. na poziomie jednorocznego budżetu państwa".

Porównując liczbę ofiar śmiertelnych w rozpatrywanym okresie (tab. 1) z prognozowaną liczbą ofiar śmiertelnych według Wizji ZERO programu Gambit 2005, można zauważyć spadek liczby ofiar śmiertelnych. Jest on jednak zbyt powolny (ryc. 7). Trudno stwierdzić, czy plan ten zostanie zrealizowany w terminach przyjętych w programie Gambit 2005. Przykładem może być rok 2007, w którym według planu realizacji Wizji ZERO liczba ofiar śmiertelnych nie powinna przekroczyć liczby 4300. Statystyki policyjne wykazały 5583 ofiary śmiertelne, zatem 
w roku 2007 plan Wizji ZERO nie został zrealizowany. Realizacja pierwszego celu etapowego planu Wizji Zero, jakim jest poziom nie więcej niż 2800 osób w roku 2013, wydaje się być zagrożona. By osiągnąć cel podstawowy, jakim jest zmniejszenie liczby ofiar śmiertelnych do poziomu zero, należy zintensyfikować działania przedsiębiorcze we wszystkich obszarach związanych z bezpieczeństwem ruchu drogowego. Szczególnie intensywne działania przedsiębiorcze należy prowadzić w obszarze edukacji, która powinna objąć trzy podstawowe grupy społeczne: dzieci, młodzież oraz dorosłych. Podstawowym celem podejmowanych działań edukacyjnych powinna być poprawa stanu wiedzy i świadomości uczestników ruchu drogowego, a szczególnie dzieci i młodzieży, w zakresie bezpiecznego poruszania się po drogach.

Ryc. 7. Ofiary śmiertelne w Polsce w latach 2006-2010 według statystyk policyjnych oraz według planu realizacji Wizji ZERO przyjętego w programie Gambit 2005

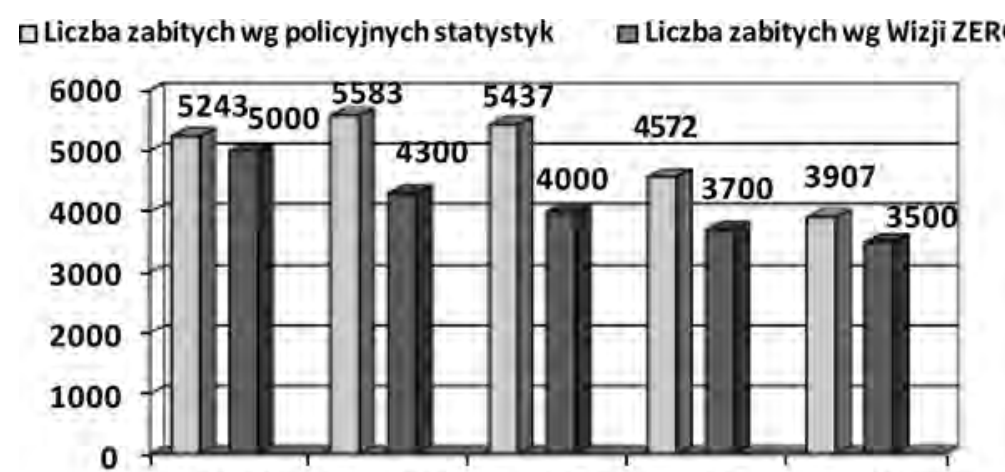

Rok 2006 Rok2007 Rok2008 Rok2009 Rok2010

Źródło: opracowanie własne na podstawie danych statystycznych KG Policji, http://dlakierowcow.policja. $\mathrm{pl} /$ portal/dk/807/47493/Wypadki_drogowe_raporty_roczne.html lipiec 2011, oraz Krajowego Programu Bezpieczeństwa Ruchu Drogowēgo „Gambit 2005”, http://www.krbrd.gov.pl/download/pdf/Gambit_2005_RM.pdf (luty 2011).

\section{Badania ankietowe - zalożenia i wyniki}

W celu oceny stanu wiedzy o zagrożeniach występujących w ruchu drogowym i świadomości bezpiecznego w nim uczestnictwa dzieci i młodzieży zostały przeprowadzone badania ankietowe na grupie 87 osób, studentów ostatniego roku pedagogiki studiów zaocznych. Takie same badania przeprowadzone zostały na 34-osobowej grupie rodziców w jednej z wyższych uczelni w Polsce. Byli to studenci studiów podyplomowych kierunków niepedagogicznych. Badania przeprowadzono w okresie jednego miesiąca na terenie pięciu miast i obejmowały one następujące obszary:

- wiedzy dzieci o zagrożeniach występujących w ruchu drogowym w ocenie pedagogów i rodziców,

- wiedzy młodzieży o zagrożeniach występujących w ruchu drogowym w ocenie pedagogów i rodziców,

- świadomości dzieci o bezpiecznym uczestnictwie w ruchu drogowym w ocenie pedagogów i rodziców, 
- świadomości młodzieży o bezpiecznym uczestnictwie w ruchu drogowym w ocenie pedagogów i rodziców,

- programy nauczania w zakresie przekazu treści kształtujących świadome i bezpieczne uczestnictwo dzieci w ruchu drogowym w opinii pedagogów,

- programy nauczania w zakresie przekazu treści kształtujących świadome i bezpieczne uczestnictwo młodzieży w ruchu drogowym w opinii pedagogów.

Rodzice nie podjęli się oceny programów nauczania w zakresie przekazu treści kształtujących świadome i bezpieczne uczestnictwo dzieci oraz młodzieży w ruchu drogowym. Wyniki badań przedstawiono na rycinach 8-11. W celu oceny obszaru wiedzy dzieci i młodzieży o zagrożeniach występujących w ruchu drogowym przyjęto następujące wskaźniki:

- ŚSW $\mathrm{Sw}_{\mathrm{sw}}$ - średni wskaźnik wiedzy liczony według zależności:

$\dot{S} W_{\mathrm{sw}}=\frac{\Sigma \mathrm{LO}_{\mathrm{ZDsw}}+\Sigma \mathrm{LO}_{\mathrm{RDsw}}}{\mathrm{Olo}_{\mathrm{sw}}} \cdot 100 \%$

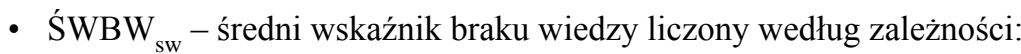

ŚWBW $_{\mathrm{sw}}=\frac{\Sigma \mathrm{LO}_{\mathrm{RZsw}}+\Sigma \mathrm{LO}_{\mathrm{ZZsw}}}{\mathrm{Olo}_{\mathrm{sw}}} \cdot 100 \%$,

gdzie:

Olo $_{s w}$ - ogólna liczba odpowiedzi,

$\Sigma \mathrm{LO}_{\text {ZDsw }}$ - liczba odpowiedzi ,zdecydowanie dobry”,

$\Sigma \mathrm{LO}_{\mathrm{RDsw}}$ - liczba odpowiedzi ,raczej dobry”,

$\Sigma \mathrm{LO}_{\mathrm{RZsw}}$ - liczba odpowiedzi „raczej zły”,

$\Sigma \mathrm{LO}_{\mathrm{ZZsw}}$ - liczba odpowiedzi ,zdecydowanie zły”.

Wyniki oceny wiedzy dzieci i młodzieży o zagrożeniach występujących w ruchu drogowym przedstawiono na rycinach 8 oraz 9 . Z przeprowadzonych przez autora badań wynikają duże rozbieżności między pedagogami i rodzicami w ocenie wiedzy dzieci o zagrożeniach występujących w ruchu drogowym. Pedagodzy wysoko ocenili stan wiedzy dzieci o zagrożeniach występujących w ruchu drogowym (ryc. 8a). Rodzice tę cechę ocenili o około 1/3 niżej (ryc. 8b). Ocena wiedzy młodzieży o zagrożeniach w ruchu drogowym dokonana przez pedagogów oraz rodziców kształtowała się na tym samym poziomie (ryc. 9). Analiza przedstawionych wyników wskazuje również, że według oceny pedagogów nastąpił spadek wiedzy młodzieży o zagrożeniach w ruchu drogowym w porównaniu $\mathrm{z}$ analogiczną wiedzą dzieci. Według oceny rodziców, wiedza młodzieży o zagrożeniach w ruchu drogowym jest na wyższym poziomie niż wiedza dzieci w tym zakresie (ryc. $8 \mathrm{~b}$ i 9b). 
Ryc. 8. Ocena cechy „stan wiedzy dzieci o zagrożeniach występujących w ruchu drogowym” dokonana przez: a) pedagogów, b) rodziców

a)

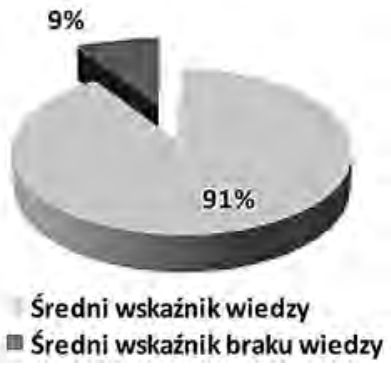

b)

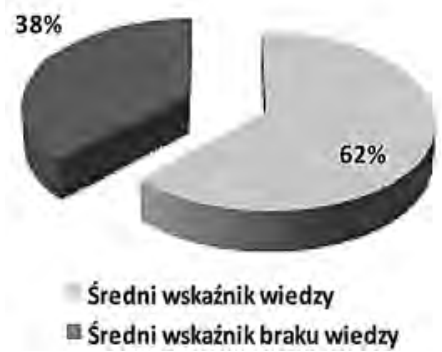

Źródło: opracowanie własne na podstawie badań własnych.

Ryc. 9. Ocena cechy „stan wiedzy młodzieży o zagrożeniach w ruchu drogowym” dokonana przez: a) pedagogów, b) rodziców

a)

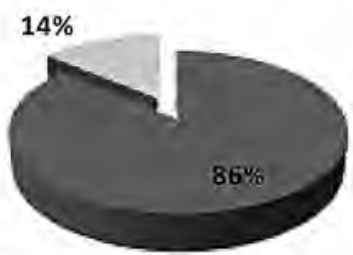

घ Średni wskaźnik wiedzy Średni wskaźnik braku wiedzy b)

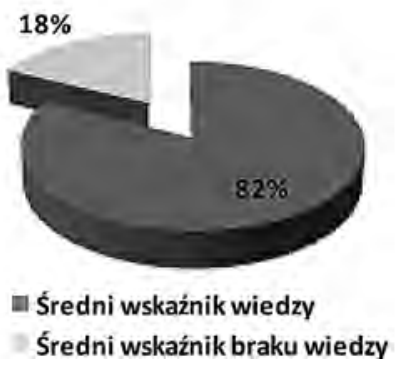

Źródło: opracowanie własne na podstawie badań własnych.

W celu oceny obszaru świadomości dzieci i młodzieży o zagrożeniach występujących w ruchu drogowym przyjęto następujące wskaźniki:

- ŚWŚs - średni wskaźnik świadomości dla cechy „stan świadomości o bezpiecznym uczestnictwie w ruchu drogowym” liczony według zależności:

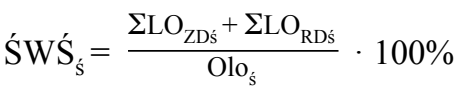

- ŚWBŚś - średni wskaźnik braku świadomości dla cechy „,stan świadomości o bezpiecznym uczestnictwie w ruchu drogowym" liczony według zależności:

$\dot{S} W B S_{\dot{s}}=\frac{\Sigma \mathrm{LO}_{\mathrm{RZs}^{\prime}}+\Sigma \mathrm{LO}_{\mathrm{ZZs}}}{\mathrm{Olo}_{\dot{s}}} \cdot 100 \%$,

gdzie:

$\mathrm{Olo}_{\hat{s}}$ - ogólna liczba odpowiedzi dla cechy „stan świadomości o bezpiecznym uczestnictwie w ruchu drogowym", 
$\Sigma \mathrm{LO}_{\text {ZDśs }}$ - liczba odpowiedzi „Zdecydowanie dobry” dla cechy „stan świadomości o bezpiecznym uczestnictwie w ruchu drogowym",

$\Sigma \mathrm{LO}_{\mathrm{RDś}}$ - liczba odpowiedzi „raczej dobry dla cechy „stan świadomości o bezpiecznym uczestnictwie w ruchu drogowym",

$\Sigma \mathrm{LO}_{\mathrm{RZss}}-$ liczba odpowiedzi „raczej zły dla cechy „stan świadomości o bezpiecznym uczestnictwie w ruchu drogowym",

$\Sigma \mathrm{LO}_{\text {ZZśs }}$ - liczba odpowiedzi „zdecydowanie zły dla cechy „stan świadomości o bezpiecznym uczestnictwie w ruchu drogowym".

Wyniki oceny świadomości dzieci i młodzieży o bezpiecznym uczestnictwie w ruchu drogowym przedstawiono na rycinie 10 .

Ryc. 10. Ocena cechy „stan świadomości dzieci o bezpiecznym uczestnictwie w ruchu drogowym” dokonana przez: a) pedagogów, b) rodziców

a)

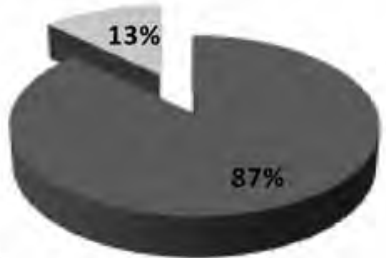

Sredni wskaźnik świadomości

Średni wskaźnik braku świadomości b)

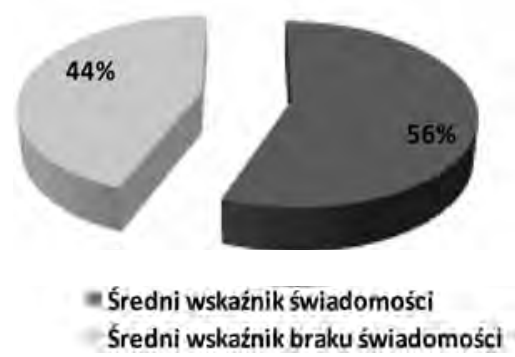

Źródło: opracowanie własne na podstawie badań własnych.

Duże rozbieżności wystąpiły w ocenie cechy „stan świadomości dzieci o bezpiecznym uczestnictwie w ruchu drogowym": pedagodzy ocenili tę cechę dzieci na $87 \%$, natomiast rodzice - na 56\%. Różnica wyniosła 31\% (ryc. 10a i ryc. 10b). Niewielkie różnice, wynoszące $7 \%$, wystąpiły przy ocenie cechy ,stan świadomości młodzieży o bezpiecznym uczestnictwie w ruchu drogowym" (ryc. 11). Według pedagogów, świadomość dzieci o bezpiecznym uczestnictwie w ruchu drogowym jest wyższa niż analogiczna świadomość młodzieży. Rodzice ocenili świadomość dzieci o bezpiecznym uczestnictwie w ruchu drogowym niżej niż świadomość młodzieży w tym zakresie. Po ukończeniu 18 roku życia młody uczestnik ruchu drogowego ma możliwość odbycia szkolenia kursowego w zakresie prawa jazdy kategorii B. W trakcie tego szkolenia uzupełnia wiedzę, a często uczy się ponownie przepisów ruchu drogowego oraz nabywa nową umiejętność uczestnictwa w ruchu drogowym, jaką jest prowadzenie pojazdu samochodowego. Testowy charakter egzaminu teoretycznego powoduje, że młody człowiek uczy się zdawania testów, a nie przepisów ruchu drogowego i bezpiecznego w nim uczestnictwa. 
Ryc. 11. Ocena cechy „stan świadomości młodzieży o bezpiecznym uczestnictwie w ruchu drogowym” dokonana przez: a) pedagogów, b) rodziców

a)

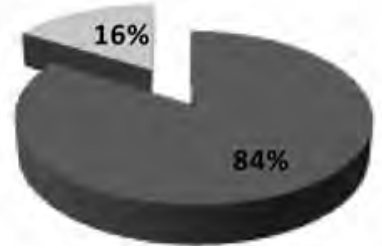

Średni wskaźnik świadomości Średni wskażnik braku świadomości b)

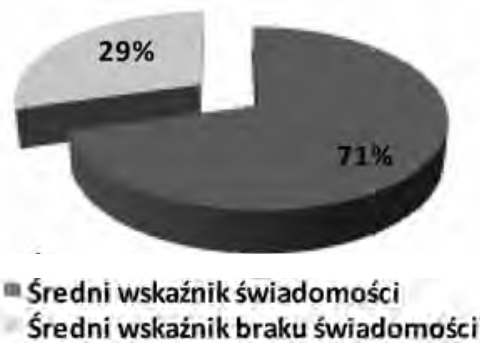

Źródło: opracowanie własne na podstawie badań własnych.

Program szkolenia kursowego kategorii B nie zawiera treści dotyczących zagrożeń występujących w ruchu drogowym oraz treści pozwalających na kształtowanie postawy świadomego i bezpiecznego uczestnictwa w ruchu drogowym. Program ten jest podsumowaniem całego procesu kształtowania postawy świadomego i bezpiecznego uczestnictwa w ruchu drogowym. Zatem czy programy nauczania na wcześniejszych etapach kształcenia pozwalają w dostatecznym zakresie przekazać treści kształtujące świadome i bezpieczne uczestnictwo dzieci i młodzieży w ruchu drogowym? W celu odpowiedzi na tak postawione pytanie zostały przeprowadzone badania ankietowe na grupie 87 osób, studentów ostatniego roku pedagogiki studiów zaocznych. Takie same badania przeprowadzone zostały na 34-osobowej grupie rodziców. Byli to studenci studiów podyplomowych kierunków niepedagogicznych. Badania przeprowadzono w okresie jednego miesiąca na terenie pięciu miast. W celu oceny programów nauczania w obszarze przekazu treści kształtujących świadome i bezpieczne uczestnictwo dzieci i młodzieży w ruchu drogowym przyjęto następujące wskaźniki:

- ŚSOP ${ }_{\text {se }}$ - średni wskaźnik oceny pozytywnej systemu edukacji dla cechy „ocena systemu edukacji w obszarze skuteczności przekazu treści kształtujących świadome i bezpieczne uczestnictwo w ruchu drogowym” liczony według zależności:

ŚWOP $_{\mathrm{se}}=\frac{\Sigma \mathrm{LO}_{\mathrm{ZDse}}+\Sigma \mathrm{LO}_{\mathrm{RDse}}}{\mathrm{Olo}_{\mathrm{se}}} \cdot 100 \%$

- ŚWON ${ }_{\text {se }}$ - średni wskaźnik oceny negatywnej systemu edukacji dla cechy „ocena systemu edukacji w obszarze przekazu treści kształtujących świadome i bezpieczne uczestnictwo w ruchu drogowym” liczony według zależności:

$\dot{S}^{\prime} \mathrm{WON}_{\mathrm{se}}=\frac{\Sigma \mathrm{LO}_{\mathrm{RZse}}+\Sigma \mathrm{LO}_{\mathrm{ZZse}}}{\mathrm{Olo}_{\mathrm{se}}} \cdot 100 \%$

gdzie:

$\mathrm{Olo}_{\text {se }}$ - ogólna liczba odpowiedzi dla cechy „ocena systemu edukacji w obszarze przekazu treści kształtujących świadome i bezpieczne uczestnictwo w ruchu drogowym”,

$\Sigma \mathrm{LO}_{\text {ZDse }}$ - liczba odpowiedzi ,zdecydowanie dobry dla cechy ocena systemu edukacji w obszarze przekazu treści kształtujących świadome i bezpieczne uczestnictwo w ruchu drogowym”, 
$\Sigma \mathrm{LO}_{\text {RDse }}$ - liczba odpowiedzi „,raczej dobry” dla cechy „ocena systemu edukacji w obszarze przekazu treści kształtujących świadome i bezpieczne uczestnictwo w ruchu drogowym”,

$\Sigma \mathrm{LO}_{\mathrm{RZse}}$ - liczba odpowiedzi „,raczej zły” dla cechy „ocena systemu edukacji w obszarze przekazu treści kształtujących świadome i bezpieczne uczestnictwo w ruchu drogowym”,

$\Sigma \mathrm{LO}_{\text {zzse }}$ - liczba odpowiedzi „zdecydowanie zły” dla cechy „ocena systemu edukacji w obszarze przekazu treści kształtujących świadome i bezpieczne uczestnictwo w ruchu drogowym”.

Wyniki tych badań przedstawiono na rycinach 12 oraz 13. Pedagodzy wysoko ocenili programy nauczania przedszkolnego oraz pierwszego i drugiego etapu kształcenia w zakresie przekazu treści dotyczących świadomego i bezpiecznego uczestnictwa w ruchu drogowym (ryc. 12 oraz ryc. 13a). Ocena ta potwierdza wysoką ocenę wiedzy dzieci o zagrożeniach występujących w ruchu drogowym oraz ich świadomości o bezpiecznym w nim uczestnictwie. Znacznie gorzej w ocenie pedagogów w zakresie przekazu treści dotyczących świadomego i bezpiecznego uczestnictwa w ruchu drogowym wypadły programy nauczania III etapu edukacyjnego (ryc. 13b). Ocena ta wyjaśnia również niską ocenę świadomości młodzieży gimnazjalnej o bezpiecznym uczestnictwie w ruchu drogowym mimo dobrej wiedzy o zagrożeniach w nim występujących. Rodzice nie udzielili odpowiedzi na pytania dotyczące oceny programów nauczania w obszarze przekazu treści z zakresu świadomego i bezpiecznego uczestnictwa w ruchu drogowym.

Ryc. 12. Ocena programów nauczania w obszarze przekazu treści kształtujących świadome i bezpieczne uczestnictwo dzieci w ruchu drogowym w opinii pedagogów: a) edukacja przedszkolna, b) edukacja I etapu kształcenia: klasy I-III

a)

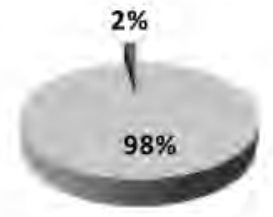

Średni wskaźnik oceny pozytywnej

- Średni wskaźnik oceny negatywnej b)

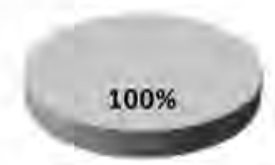

Średni wskażnik oceny pozytywnej

éśredni wskażnik oceny negatywnej

Źródło: opracowanie własne na podstawie badań własnych

Ryc. 13. Ocena programów nauczania w obszarze przekazu treści kształtujących świadome i bezpieczne uczestnictwo dzieci w ruchu drogowym w opinii pedagogów: a) edukacja II etapu kształcenia: klasy IV-VI, b) edukacja III etapu kształcenia: gimnazjum

a)

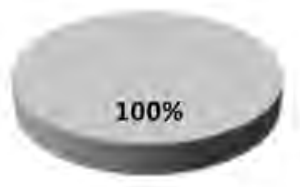

Średni wskaźnik oceny pozytywnej b)

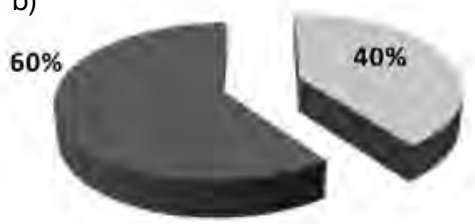

Średni wskaźnik oceny pozytywnej

"= Średni wskaźnik oceny negatywnej

Źródło: opracowanie własne na podstawie badań własnych. 


\section{Wnioski}

Analiza wyników badań pozwoliła sformułować dwie grupy wniosków: pierwsza grupa to wnioski dotyczące obecnego stanu wiedzy dzieci i młodzieży o zagrożeniach występujących w ruchu drogowym oraz świadomości o bezpiecznym w nim uczestnictwie, druga grupa to wnioski dotyczące programów nauczania i ich realizacji. Wnioski z analizy obszaru wiedzy dzieci i młodzieży o zagrożeniach występujących w ruchu drogowym oraz z analizy obszaru świadomego i bezpiecznego uczestnictwa dzieci i młodzieży w ruchu drogowym zestawiono w tabeli 4. Rozbieżności między pedagogami a rodzicami w ocenie obszaru wiedzy dzieci o zagrożeniach w ruchu drogowym oraz obszaru świadomego i bezpiecznego w nim uczestnictwa wynikają z faktu, że rodzice często sami popełniają błędy, np. przeprowadzając dziecko przez jezdnię w niedozwolonym miejscu, co pozwala im tego typu błędy popełniane przez dzieci uważać za zachowanie prawidłowe lub je tolerować. Takie postępowanie rodziców powoduje powstanie w umyśle dziecka następującego problemu: nauczyciele uczą, że zgodnie z Prawem o ruchu drogowym przejście przez jezdnię dozwolone jest w miejscu do tego przeznaczonym, z drugiej strony rodzice nie zawsze przeprowadzają mnie po przejściu dla pieszych, więc czy muszę przestrzegać przepisów o ruchu drogowym? Częstym efektem takiej rozterki dziecka spowodowanej niezgodnym z prawem o ruchu drogowym postępowaniem rodziców czy dziadków jest szybkie przebieganie przez jezdnię w miejscu niedozwolonym bez sprawdzenia możliwości przejścia. Negatywnym efektem wychowawczym niezgodnego z prawem o ruchu drogowym postępowania rodziców jest obniżenie efektów pracy pedagogów nad budową i kształtowaniem prawidłowej postawy dziecka do świadomego i bezpiecznego uczestnictwa w ruchu drogowym. Te same obszary w odniesieniu do młodzieży były różnie ocenione przez pedagogów i rodziców. W obszarze wiedzy młodzieży o zagrożeniach w ruchu drogowym rodzice i pedagodzy byli zgodni - według ich oceny jest to wiedza na wysokim poziomie pozwalającym na zgodne $\mathrm{z}$ prawem uczestnictwo w ruchu drogowym.

Tab. 4. Wnioski z analizy obszarów badawczych: wiedza dzieci i młodzieży o zagrożeniach występujących w ruchu drogowym oraz świadome i bezpieczne uczestnictwo dzieci i młodzieży w ruchu drogowym

\begin{tabular}{|l|l|l|l|}
\hline \multicolumn{4}{|c|}{ Obszary badawcze } \\
\hline \multicolumn{2}{|c|}{$\begin{array}{c}\text { wiedza o zagrożeniach występujących } \\
\text { w ruchu drogowym }\end{array}$} & \multicolumn{1}{c|}{$\begin{array}{c}\text { świadome i bezpieczne uczestnictwo } \\
\text { w ruchu drogowym }\end{array}$} \\
\hline \multicolumn{1}{|c|}{ dzieci } & \multicolumn{1}{c|}{ dzieci } & \multicolumn{1}{c|}{ młodzież } \\
\hline $\begin{array}{l}\text { brak zgodności ocen } \\
\text { pedagogów (91\%) } \\
\text { i rodziców (62\%) }\end{array}$ & $\begin{array}{l}\text { zgodność ocen } \\
\text { pedagogów (86\%) } \\
\text { i rodziców (82\%) }\end{array}$ & $\begin{array}{l}\text { brak zgodności ocen } \\
\text { pedagogów (87\%) } \\
\text { i rodziców (56\%) }\end{array}$ & $\begin{array}{l}\text { brak zgodności ocen } \\
\text { pedagogów (84\%) } \\
\text { i rodziców (71\%) }\end{array}$ \\
\hline $\begin{array}{l}\text { według oceny pedagogów, przejściu dziecka } \\
\text { do kolejnego etapu kształcenia towarzyszy spadek } \\
\text { wiedzy w tym obszarze }\end{array}$ & $\begin{array}{l}\text { według oceny pedagogów, przejściu dziecka } \\
\text { do kolejnego etapu kształcenia towarzyszy spadek } \\
\text { świadomości w tym obszarze }\end{array}$ \\
\hline $\begin{array}{l}\text { według oceny rodziców, przejściu dziecka } \\
\text { do kolejnego etapu kształcenia towarzyszy wzrost } \\
\text { wiedzy w tym obszarze }\end{array}$ & $\begin{array}{l}\text { według oceny rodziców, przejściu dziecka } \\
\text { do kolejnego etapu kształcenia towarzyszy wzrost } \\
\text { świadomości w tym obszarze }\end{array}$ \\
\hline
\end{tabular}

Źródło: opracowanie własne. 
W ocenie obszaru świadomego i bezpiecznego uczestnictwa młodzieży w ruchu drogowym wystąpiły rozbieżności: pedagodzy wyżej ocenili ten obszar niż rodzice. Różnica może wynikać z faktu, że rodzice powtarzają błędy, które popełniali wobec dzieci, wynikające z pośpiechu i lekceważenia przepisów Prawa o ruchu drogowym oraz nieświadomego braku poszanowania życia własnego i innych uczestników ruchu drogowego. Inną bardzo ważną przyczyną tej rozbieżności jest brak wiary rodziców co do nabytej już przez dzieci wiedzy z zakresu świadomego i bezpiecznego uczestnictwa w ruchu drogowym oraz nadmierna obawa i troska o bezpieczeństwo dziecka. Takie postępowanie rodziców pogłębia postawę braku poszanowania przepisów o ruchu drogowym, poszanowania prawa innych jego uczestników, braku szacunku dla zdrowia i życia własnego i innych uczestników ruchu drogowego oraz stwarza podstawy do niebezpiecznych zachowań na drodze. $Z$ porównania oceny poziomu wiedzy dzieci o zagrożeniach występujących w ruchu drogowym $\mathrm{z}$ analogiczną oceną poziomu wiedzy młodzieży dokonaną przez pedagogów wynika, że przejściu dziecka do kolejnego etapu edukacji towarzyszy obniżenie poziomu wiedzy w tym obszarze. Towarzyszy temu spadek świadomości o bezpiecznym uczestnictwie w ruchu drogowym, co skutkuje nieukształtowaną postawą młodego człowieka do świadomego i bezpiecznego uczestnictwa w ruchu drogowym. Według oceny pedagogów, programy nauczania zawierają treści z zakresu bezpieczeństwa ruchu drogowego, lecz są one rozproszone na wiele przedmiotów nauczania, a sposób ich realizacji pozostawia wiele do życzenia (tab. 5).

Tab. 5. Wnioski z analizy obszaru badawczego: przekaz treści dotyczących zasad bezpieczeństwa w ruchu drogowym zawartych w programach nauczania poszczególnych etapów kształcenia

\begin{tabular}{|l|l|l|l|}
\hline \multicolumn{4}{|c|}{$\begin{array}{l}\text { Obszar badawczy: przekaz treści dotyczących zasad bezpieczeństwa w ruchu drogowym } \\
\text { zawartych w programach nauczania poszczególnych etapów kształcenia }\end{array}$} \\
\hline $\begin{array}{l}\text { Programy nauczania } \\
\text { wychowania } \\
\text { przedszkolnego }\end{array}$ & $\begin{array}{l}\text { Programy nauczania } \\
\text { I etapu edukacyjnego: } \\
\text { klasy I-III }\end{array}$ & $\begin{array}{l}\text { Programy nauczania } \\
\text { II etapu edukacyjnego: } \\
\text { klasy IV-VI }\end{array}$ & $\begin{array}{l}\text { Programy nauczania } \\
\text { III etapu edukacyjnego: } \\
\text { gimnazjum }\end{array}$ \\
\hline $\begin{array}{l}\text { W 98\% pozwalają } \\
\text { przekazać treści } \\
\text { programowe }\end{array}$ & $\begin{array}{l}\text { W 100\% pozwalają } \\
\text { przekazać treści } \\
\text { programowe }\end{array}$ & $\begin{array}{l}\text { W 100\% pozwalają } \\
\text { przekazać treści } \\
\text { programowe }\end{array}$ & $\begin{array}{l}\text { W 40\% pozwalają } \\
\text { przekazać treści } \\
\text { programowe }\end{array}$ \\
\hline
\end{tabular}

Źródło: opracowanie własne.

W wychowaniu przedszkolnym oraz w I etapie kształcenia (klasy I-III) programy nauczania w zakresie świadomego i bezpiecznego uczestnictwa dzieci w ruchu drogowym są w pełni realizowane między innymi w formie ćwiczeń i zabaw symulacyjnych. W II etapie kształcenia programy nauczania w zakresie zasad bezpieczeństwa ruchu drogowego realizowane są bezpośrednio w ramach przedmiotu technika, pośrednio - na pozostałych przedmiotach oraz jako program wychowawczy szkoły. W tym etapie realizacja treści programowych z zakresu świadomego i bezpiecznego uczestnictwa dzieci w ruchu drogowym charakteryzuje się brakiem systematyczności, ciągłości oraz realizmu i kończy się najczęściej uzyskaniem przez 10-latka karty rowerowej. W III etapie kształcenia, najczęściej w klasie III, a więc po 2-letniej przerwie, w części gimnazjów, okazjonalnie i niesystematycznie realizuje się treści programowe z zakresu świadomego i bezpiecznego uczestnictwa młodzieży w ruchu drogowym. I na tym kończy się edukacja naszych dzieci dotycząca świadomego i bezpiecznego uczestnictwa w ruchu drogowym. W efekcie młodzież kończąca III etap edukacyjny nie ma poprawnie ukształtowanej 
postawy świadomego i bezpiecznego uczestnictwa w ruchu drogowym. W szkole ponadgimnazjalnej wiedza z zakresu ruchu drogowego jest przekazywana w szkołach o kierunkach samochodowych i rolniczych. W szkołach ponadgimnazjalnych o innych kierunkach oraz liceach ogólnokształcących programy nauczania nie przewidują nauczania przepisów ruchu drogowego. Dla uczniów tych szkół pozostaje tylko profesjonalne szkolenie kursowe w ośrodku szkolenia kierowców. W efekcie do dalszych etapów kształcenia w zakresie bezpieczeństwa w ruchu drogowym przechodzi młody człowiek mający mgliste pojęcie o podstawowych zasadach ruchu drogowego i bez wyrobionych nawyków świadomego i bezpiecznego zachowania się na drodze. W podsumowaniu wniosków można stwierdzić, że sugerowany w programie Gambit 2005 oraz przyjęty przez Ministerstwo Edukacji Narodowej interdyscyplinarny charakter nauczania zasad świadomego i bezpiecznego uczestnictwa w ruchu drogowym:

- sprawdza się w edukacji przedszkolnej oraz w I etapie kształcenia, czyli w klasach I-III, mimo że treści te w I etapie przekazywane są w ramach przedmiotu technika,

- nie sprawdza się w II etapie, czyli w klasach IV-VI ze względu na duże rozproszenie treści zasad bezpieczeństwa w ruchu drogowym oraz sposób ich realizacji,

- nie sprawdza się w III etapie, tj. w gimnazjum również ze względu na duże rozproszenie treści zasad bezpieczeństwa w ruchu drogowym oraz zły sposób ich realizacji.

Z przedstawionych wniosków wynika, że należy kontynuować interdyscyplinarny charakter nauczania zasad świadomego i bezpiecznego uczestnictwa w ruchu drogowym, który sprawdza się w edukacji przedszkolnej oraz w I etapie kształcenia. W etapach II i III interdyscyplinarny charakter przekazu treści z zakresu bezpieczeństwa ruchu drogowego nie sprawdza się, należy więc w etapie II wyodrębnić oddzielny przedmiot nauczania zawierający te treści, który można nazwać wychowanie dla bezpiecznego uczestnictwa w ruchu drogowym. Przedmiot ten powinien być kontynuowany w etapie III, czyli w gimnazjum i w etapie IV, czyli w szkołach ponadgimnazjalnych, w tym w szkołach zasadniczych, niezależnie od prowadzonego przez nie kierunku kształcenia. Dla nowego przedmiotu konieczne byłoby opracowanie nowej podstawy programowej uwzględniającej treści dotyczące przepisów o ruchu drogowym, potencjalnych zagrożeń występujących w ruchu drogowym, zasad bezpiecznego zachowania w ruchu drogowym, poszanowania prawa o ruchu drogowym, etykę uczestnika ruchu drogowego oraz obowiązkowy egzamin teoretyczny i praktyczny odpowiednio do etapu kształcenia. Kolejnym działaniem byłoby opracowanie jednego programu nauczania dla każdego etapu kształcenia i jego konsekwentna realizacja. Program nauczania II etapu powinien uwzględniać obowiązkowy egzamin na kartę rowerową, a program etapu III powinien uwzględnić w treści przygotowanie do obowiązkowego egzaminu na kartę motorowerową. IV etap kształcenia powinien zakończyć obowiązkowym egzaminem teoretycznym i praktycznym. Pozytywny wynik tego egzaminu dałby prawo przystąpienia do szkolenia kursowego w zakresie kategorii $\mathrm{B}$, które poprzedza szkolenia na inne kategorie prawa jazdy. Programy nauczania dla wszystkich etapów kształcenia powinny zawierać w swych treściach etykę uczestnika ruchu drogowego. Przedstawione propozycje działań przedsiębiorczych powinny przyczynić się do ukształtowania postawy świadomego i bezpiecznego uczestnictwa w ruchu drogowym, a tym samym do poprawy bezpieczeństwa na polskich drogach. 


\section{Literatura}

1. Brzozowski T.T., 2007, Przedsiębiorczość - pojęcie polisemiczne czy niewłaściwie rozumiane? Próba systematyzacji [w:] Rola przedsiębiorczości w aktywizacji gospodarczej, Z. Zioło, T. Rachwał (red.), „Przedsiębiorczość - Edukacja”, nr 3, wydawnictwo Nowa Era, Zakład Przedsiębiorczości i Gospodarki Przestrzennej Akademii Pedagogicznej im. Komisji Edukacji Narodowej w Krakowie, Warszawa - Kraków, s. 198-203.

2. Chmielewski J., Szczuraszek T., 2005, Gromadzenie danych o zdarzeniach drogowych [w:] Bezpieczeństwo ruchu drogowego, T. Szczuraszek (red.), WKiŁ, Warszawa, s. 14-41.

3. Huczek M., 2009, Zarządzanie jako czynnik rozwoju przedsiębiorczości [w:] Rola przedsiębiorczości w kształtowaniu spoleczeństwa informacyjnego, Z. Zioło, T. Rachwał (red.), „Przedsiębiorczość Edukacja”, nr 5, wydawnictwo Nowa Era, Zakład Przedsiębiorczości i Gospodarki Przestrzennej Instytutu Geografii Uniwersytetu Pedagogicznego im. Komisji Edukacji Narodowej w Krakowie, Warszawa - Kraków, s. 88-98.

4. Kupisiewicz Cz., Kupisiewicz M., 2009, Stownik pedagogiczny, PWN, Warszawa.

5. Komenda Główna Policji, Dane statystyczne wypadków drogowych: Dlugie weekendy i święta: Weekend majowy, http://dlakierowcow.policja.pl/portal/dk/834/47562/Weekend_majowy.html (dostęp: lipiec 2011).

6. Komenda Główna Policji, Dane statystyczne wypadków drogowych: Dlugie weekendy i święta: Weekend sierpniowy, http://dlakierowcow.policja.pl/portal/dk/834/47565/Weekend_sierpniowy.html (dostęp: lipiec 2011).

7. Komenda Główna Policji, Wypadki drogowe - raporty roczne, http://dlakierowcow.policja.pl/portal/ dk/807/47493/Wypadki_drogowe_raporty_roczne.html (dostęp: lipiec 2011).

8. Makieła Z., Rachwał T., 2010, Podstawy przedsiębiorczości. Podręcznik dla liceum ogólnoksztatcacego, liceum profilowanego i technikum, wydawnictwo Nowa Era, Warszawa.

9. Mazur A., 2005, Rola szkolnej edukacji komunikacyjnej w poprawie bezpieczeństwa ruchu drogowego, http://www.sp1rumia.fc.pl/publikacje/wychkomunik.pdf (dostęp: sierpień 2011).

10. Merkisz J., Nowakowski T., Smalko Z., 2007, Bezpieczeństwo w transporcie [w:] Uwarunkowania rozwoju systemu transportowego Polski, B. Liberadzki, L. Mindura (red.), Instytut Technologii Eksploatacji - Państwowy Instytut Badawczy, Warszawa - Radom, s. 499-561.

11. Ministerstwo Infrastruktury, Krajowy Program Bezpieczeństwa Ruchu Drogowego 2005 - 2007 - 2013 Gambit 2005, http://www.krbrd.gov.pl/download/pdf/Gambit_2005_RM.pdf (dostęp: luty 2011).

12. Okoń W., 1998, Nowy stownik pedagogiczny, Żak, Wydawnictwo Akademickie, Warszawa.

13. Ożdżyński Z., 2010, Transfer wiedzy a bezpieczeństwo ruchu drogowego [w:] Szkoły wyższe w gospodarce regionów, J. Wernik, K.J. Wołosz (red.), Oficyna Wydawnicza Politechniki Warszawskiej, Warszawa, s. 140-146.

14. Zielińska S., Bezpieczeństwo dzieci i młodzieży. Szkolna edukacja motoryzacyjna, http://prbrd.gda. $\mathrm{pl} /$ wp-content/themes/prbrd/pliki/edukacja_motoryzacyjna.pdf (dostęp: luty 2011). 


\section{Entrepreneurship in children and young people education on conscious and safe participation in the road traffic}

The article presents the results of studies related to children and adolescents' awareness of the road dangers and their conscious and safe participation in the road traffic. Additionally it indicates stages of education, which should undergo changes resulting in the safety improvement on the Polish roads.

The conclusions of the study are compared with the intentions of the National Road Safety Programme Gambit 2005 in the field of education referring to the road safety and the conclusions of the analysis of safety on Polish roads.

The article discusses the erroneous actions of adults towards children entailing failures in traffic laws observance by children and adolescents. 